\title{
Customer Loyalty and the Effects of Commitment towards Suppliers in Malaysian Electrical and Electronics Manufacturing Industry
}

\author{
Soon-Chee, Leong*, Maria Abdul Rahman \\ College of Business, Universiti Utara Malaysia, Malaysia
}

Received July 26, 2019; Revised September 19, 2019; Accepted September 26, 2019

Copyright@2019 by authors, all rights reserved. Authors agree that this article remains permanently open access under the terms of the Creative Commons Attribution License 4.0 International License

\begin{abstract}
This study investigates the influences of product quality and relational elements, namely trust, cooperation, and communication, on customer loyalty, and mediating effects of commitment in Malaysian electrical and electronics manufacturing industry. It utilizes quantitative methodology, where survey questionnaires are sent to Malaysian electrical and electronics manufacturing firms selected from two directories. A total of 267 returned and useable survey questionnaires were used for data analysis consisting of descriptive analysis, PLS-SEM, and mediation effects. Results of PLS-SEM analysis found that product quality and cooperation have significant influences on customer loyalty. In contrast, trust and communication do not have significant influence on customer loyalty. Mediation effect analysis findings established that commitment significantly mediates four relationships between product quality and customer loyalty, trust and customer loyalty, cooperation and customer loyalty, and communication and customer loyalty. Two relationships between product quality and customer loyalty, and cooperation and customer loyalty are partially mediated by commitment. The other two relationships between trust and customer loyalty, and communication and customer loyalty are fully mediated by commitment. The findings have managerial implications for Malaysian electrical and electronics manufacturing industry, where customer loyalty can be developed with influences of product quality and relational elements, in which not all of them develop customer loyalty in similar way; only cooperation has direct influence on customer loyalty. Nevertheless, with the presence of mediating effects of commitment, all three relational elements can develop customer loyalty indirectly.
\end{abstract}

Keywords Customer Loyalty, Product Quality, Relational Elements, Commitment, Manufacturing

\section{Introduction}

Malaysia is considered one of the global manufacturing hubs for electrical and electronics (E\&E) products. E\&E industry leads the Malaysian manufacturing sector with significant contributions to economy, employment and development of supply chain related industries. Notwithstanding the important contributions of Malaysian manufacturing E\&E industry, however, it is experiencing challenges that are adversely affecting export growth in recent decade (Bank Negara Malaysia [1]). It is subjected to many challenges, ranging from global competitions, rapid technological innovations, to cyclical demands. These challenges are further compounded by recent development, where E\&E customers are consolidating their supplier bases by holding fewer suppliers (Li[2]). This shift of supply chain management has created profound impact on suppliers, who must compete and differentiate themselves by delivering values beyond merely selling products. The tasks of getting into the customer Approved Supplier List (ASL), and to defend the position there amidst competitions have become an issue of utmost concern to suppliers. Establishing customer loyalty and commitment have become more important than ever.

Against these challenges in the Malaysian E\&E manufacturing industry, it has become pressing issues for suppliers to develop better understanding on customer loyalty, and the effects of commitment. However, establishing customer loyalty and commitment in Malaysian E\&E manufacturing industry can be complex tasks, which often involve various variables and different approaches. Apart from this, the extant business literatures provide less attention on the development of customer 
loyalty and the effects of commitment in Malaysian E\&E manufacturing industry context. This study intends to narrow the knowledge gaps, and provide insight to practitioners in Malaysian E\&E manufacturing industry by investigating influences of product quality, and relational elements, namely trust, cooperation, and communication, towards customer loyalty, and the mediating effects of commitment.

The study aims to seek answers to two research questions, namely 1) Do product quality, and relational elements, namely trust, cooperation, and communication, influence customer loyalty of Malaysian E\&E manufacturing firms toward their suppliers in Malaysian E\&E manufacturing industry?, and 2) Does commitment mediate the relationships between product quality and customer loyalty, trust and customer loyalty, cooperation and customer loyalty, and communication and customer loyalty of Malaysian E\&E manufacturing firms toward their suppliers in Malaysian E\&E manufacturing industry? The study is organized according to research context, literature review and hypotheses development, research design, data analysis, testing of hypotheses and findings. It ends by offering contributions, managerial implications, and limitations of this study.

\section{Literature Review and Hypotheses Development}

In E\&E manufacturing industry, suppliers should have products that can be offered to customers before they develop relationships around the products. Customers are not interested to establish relationships with suppliers for the sake of relationships themselves, unless the products meet specifications and provide values. As such, it is important for suppliers to manufacture and provide products with consistent quality. Product quality has not only enabled suppliers to compete, and differentiate against competitors, it can act as entry barrier to prevent entry of new suppliers from competing in the same market sector. Notwithstanding the important of product quality, however in recent years, suppliers in Malaysian E\&E manufacturing industry are facing difficulties to compete against competitors due to the advancement of manufacturing technologies available that narrow the gap of product differentiation. Relationship marketing has become increasingly important to build relationships around the products with customers. Such relationships develop customer loyalty, which are difficult to imitate by competitors in the E\&E manufacturing industry (Wu, Chen \& Chen [3]).

Product quality can influence customer loyalty directly and as well as indirectly the presence of mediating effect of commitment (Cater \& Cater [4]). Relationship marketing complement product quality by developing customer loyalty via the influences of prominent relational elements, namely trust, cooperation and communication. Relational elements can indirectly influence customer loyalty with mediating effects of commitment, in addition to their direct influences on customer loyalty. This concept is adopted to investigate both the direct influences and indirect influences (via mediating effect of commitment) of product quality, and relational elements, namely trust, cooperation, and communication, towards customer loyalty in this study.

It is widely held that commitment plays influential mediating role in enabling relationship benefits (Morgan \& Hunt [5]). Within the context of Malaysian E\&E manufacturing industry, value proposition is important in business relationship, as customers are willing to work and make commitment to suppliers who can offer values, such as product quality, trust, cooperation, and communication that are critical to the operations. For instance, suppliers with high degree of trust provide value by protecting intellectual properties, which is critically important for customers to prevent imitations by competitors. Customer commitment is essential to suppliers because of its important effect on customer loyalty (Kim, Kim \& Lee [6]). Due its linkages to both predictors, namely product quality, trust, cooperation and communication, and customer loyalty, commitment plays important role in mediating the relationships between the predictors and customer loyalty. Moreover, De Ruyter, Moorman, and Lemmink [7] identified commitment as most important mediating variable in business relationships. Thus, this study contends and adopts the perspective that commitment mediates relationships between product quality and customer loyalty, trust and customer loyalty, cooperation and customer loyalty, and communication and customer loyalty in Malaysian E\&E manufacturing industry.

\subsection{Customer Loyalty}

Customer loyalty is important to suppliers in Malaysian E\&E manufacturing industry, because it enables the benefits of repeated and frequent purchases from loyal customers, reduce inventory level and inventory cost, minimize operational costs, positive word of mouth and advocacy from loyal customers, take advantage of price insensitiveness despite alternatives are available to the loyal customers, and collaboration with loyal customers on new product and technological developments. Essentially, customer loyalty leads to profitability and business sustainability for the supplier businesses. Furthermore, Hetesi [8] reported that customer loyalty can exist even in time of economic recessions, which are not uncommon in the E\&E manufacturing industry.

Generally, there are three main streams of studies emerge on customer loyalty in the extant business literatures (Loureiro \& Kastenholz [9]). The three streams are behavioural loyalty, attitudinal loyalty, and composite concept of customer loyalty. Composite concept of 
customer loyalty comprises both aspects of behavioural loyalty and attitudinal loyalty. This study adopts the composite concept of customer loyalty, which is defined as "the mind-set of a customer, who hold a favourable attitude toward a company, commits to repurchase the company's products (or services), and recommends the products (or services) to others" (as cited in Rai [10]). It includes aspects of behavioural loyalty, and attitudinal loyalty.

\subsection{Commitment}

The concept of commitment originated from industrial and organizational psychology (Moorman, Zaltman, \& Deshpande [11]), and implies the intention to continue a course of action, such as maintaining a relationship with partner firms. Moorman et al.[11] defined commitment as "an enduring desire to maintain a value relationship". The phase "enduring desire...." suggested that both suppliers and customers want the relationships to sustain and willing to take actions to fulfil agreed terms and conditions for the relationships to remain existence. Specifically, commitment is meant for long term, and do not change frequently. This study adopts this definition, which is conceptualized as a global construct.

Relationship marketing studies have demonstrated that commitment affects customer loyalty in several ways. Doma [12] adopted a global construct for customer loyalty, and has shown the relationship between commitment and customer loyalty is positively significant. In addition, Cater and Cater [4] adopted a multidimensional constructs for customer loyalty, which consisted of attitudinal loyalty and behavioural loyalty, and determined that commitment has significant effects on both attitudinal loyalty, and behavioural loyalty. Drawing from the findings of previous marketing relationship studies, commitment has significant relationship with customer loyalty. This study hypothesizes that commitment has significant influence on customer loyalty of Malaysian E\&E manufacturing firms towards their suppliers in Malaysian E\&E manufacturing industry.

H1: Commitment has significant influence on customer loyalty.

\subsection{Product Quality}

The most common approach to defining product quality in manufacturing industry is based on the postulation from Garvin [13], who emphasized on consistency in meeting requirements, particularly on performance, conformance, and reliability. Crosby [14] defines product quality as “conformance to specification”. This definition provides objective rather than subjective measurement for product quality. For instance, customers state the specifications for suppliers to manufacture or supply the products. Products meeting the specifications are known as quality products, and are accepted by customers. Products failing to conform to specifications are considered as rejects, and not accepted by customers. As such, the definition ensures consistency, namely conformance, reliability and performance, as measured by the suppliers and customers. This definition of product quality is adopted by this study.

Findings from previous relationship marketing and supply chain literatures have demonstrated that product quality has significant effect on customer loyalty. Sadeghi, Mollahosseini, and Forghani[15] determined that product quality has significant direct influence on both the attitudinal loyalty and behavioural loyalty. In addition, Cater and Cater [4] verified the relationship between product quality and customer loyalty in the B2B (business-to-business) manufacturing industries. They determined that product quality has significant direct effect on attitudinal loyalty and behavioural loyalty. Drawing from the findings of previous relationship marketing, and supply chain studies, there are strong evidences that product quality is positively related to customer loyalty. Henceforth, this study hypothesizes that product quality has significant influence on customer loyalty of Malaysian E\&E manufacturing firms towards their suppliers in Malaysian E\&E manufacturing industry.

H2: Product quality has significant influence on customer loyalty.

Customers prefer to purchase products with highest quality to add maximum values into their final products. They commit to the relationships with suppliers to ensure the supplies of products with consistent quality. Product quality is an indispensable element of relationship value for customers. Lin and Huang [16] pointed out that suppliers and customers may jointly develop products during new product development (NPD) phases in manufacturing industry. Customers can be locked-in or calculative committed to the relationships, and are difficult to replace the suppliers or substitute the newly developed products without risking product quality. Thus, product quality exhibits influencing role on commitment in the relationships. These arguments have provided evidences that product quality has direct effect on commitment. Henceforth, this study proposes the hypothesis that product quality has significant influence on commitment of Malaysian E\&E manufacturing firms toward their suppliers in Malaysian E\&E manufacturing industry.

H3: Product quality has significant influence on commitment.

\subsection{Trust}

Trust has been defined as "a willingness to rely on an exchange partner in whom one has confidence” (Moorman et al. [11]). This definition encompasses two aspects. The first aspect views trust as a belief of the trustee's capability, credibility, reliability, integrity, and trustworthy. The 
second aspect involves behavioural intention to depend on the trustee. Moorman et al.[11] explained that both the belief and behavioural aspects must be present in order for trust to exist in the relationship. This definition of trust, which takes into consideration the aspects of belief and inter-organizational, is adopted by this study.

E\&E manufacturing industry is subjected to frequent economic cycles, in which suppliers are actively seeking ways to stay ahead of competition. Many of them react by establishing trusting relationships with customers. Such relationships are characterized by high degree of trust between the suppliers and customers. The high degree of trust enables the suppliers to pay attention on working together with customers to develop long-term mutual benefits, increase competiveness, and minimizing transaction cost. Essentially, such trusting relationships lead to customer loyalty. In the Egyptian B2B shipping sector, Doma[11] studied the effects of trust, commitment, and satisfaction on customer loyalty. Satisfaction, trust, and commitment were found to have significant direct effect on customer loyalty. He went further to discover that trust is the most important factor in influencing customer loyalty. Judging from the above arguments, there are strong evidences supporting trust has direct influence on customer loyalty. Therefore, this study proposes the hypothesis that trust has significant direct influence on customer loyalty of Malaysian E\&E manufacturing firms toward their suppliers in Malaysian E\&E manufacturing industry.

H4: Trust has significant direct influence on customer loyalty.

Velazquez, Gil-Saura, and Molina [17] determined that the continuity of a business relationship in B2B travel industries is dependable upon the ability to develop relationship between trust and commitment. Jiang, Henneberg, and Naude[18] determined the trust-commitment relationship plays crucial role in maintaining business relationship in construction industries. Chao, Yu, Cheng, and Chuang [19] validated that the trust-commitment relationship exist in the medical device supply industry. Additionally, trust can lead to higher degree of commitment (Schiele, Veldman, Huttinger, and Pulles[20]). Based on the arguments above, there are evidences that trust has direct influence on commitment. Henceforth, this study proposes the hypothesis that trust has significant influence on commitment of Malaysian E\&E manufacturing firms towards their suppliers in Malaysian E\&E manufacturing industry.

H5: Trust has significant influence on commitment.

\subsection{Cooperation}

In the E\&E manufacturing industry, a supplier's competitiveness depends more than its own capabilities to develop resources, technologies, and market. Equally important is the relationship with customers through which new products and markets are co-developed through cooperation. The ability to gain such value from the relationship, to a large extent, depends on how cooperative between them. The cooperative relationship can be a competitive advantage to the customer and supplier, because the specificity of relationship cannot be easily imitated by competitors.

In this study, cooperation can then be defined as "similar or complementary coordinated actions taken by firms in interdependent relationship to achieve mutual or singular outcomes with expected reciprocation over time" (Anderson \& Narus[21]). This definition implies that cooperation is nurtured over long period of time, and consists of many coordinated efforts from the supplier and customer to achieve mutual benefits. The supplier and customer are concerned not about itself only, but also about the welfare and interests of each other's. In the cooperative relationship, cooperation emphasizes that supplier and customer work together jointly and being flexible in response to changing situations or to accommodating each other's needs, in order to achieve mutual benefits (Cannon \& Perreault [22]).

Pecinova, Lostakova, and Branska[23] demonstrated that cooperation positively affected customer loyalty. According to their study, a firm cooperates by investing in the relationship to be able to effectively create highest possible perceived value for customer. In return, the supplier gains reciprocity benefits, in term of long term business stability, growth and profitability. Accordingly, the suppliers and customers, stay loyal to the cooperative relationship. As such, cooperation is indeed an important predictor to customer loyalty. The important to maintaining cooperative long term relationship has been emphasized by McDonnell, Beatson, and Huang [24]. In the study on B2B franchisee loyalty toward franchisor, they determined a highly cooperatively relationship creates high level of loyalty toward franchisor. Studies conducted by Yang, Chen, and Chien 25] found similar highly cooperative environment has significant influence on customer loyalty. Accordingly, when the relationship is highly cooperative, their finding indicated high degree of customer loyalty exists toward the supplier. Cooperation is a crucial factor that affects customer loyalty, and should be emphasized in the business relationship. In summary, previous relationship marketing studies have provided amble evidences to demonstrate the relationship between cooperation and customer loyalty is significant. Therefore, this study proposes the hypothesis that cooperation has significant influence on customer loyalty of Malaysian E\&E manufacturing firms towards suppliers in Malaysian E\&E manufacturing industry.

H6: Cooperation has significant influence on customer loyalty.

Sharma, Young, and Wilkinson [26] pointed out that value-based commitment can increase in conjunction with cooperativeness between supplier and customer, who 
receive greater values from working together. As such, supplier and customer in highly cooperative relationship develop a sense of moral obligation to continue the relationship. When sense of moral obligation is present in the cooperative relationship, they are more inclined to commit to the relationship. Hutchinson, Singh, Svensson, and Mysen[27] argued that cooperation is a distinct dimension of relationship quality, which comprises of ten inter-related dimensions. They concluded that cooperation is not only a distinct dimension, it is also correlated with the other nine dimensions of marketing relationship quality, which includes commitment. Judging the above arguments, there are sufficient evidences that cooperation is positively related to commitment. Henceforth, this study proposes the hypothesis that cooperation has significant influence on commitment Malaysian E\&E manufacturing firms towards suppliers in Malaysian E\&E manufacturing industry.

H7: Cooperation has significant influence on commitment.

\subsection{Communication}

Communication is a process of sharing meaningful information between supplier and customer. The process of communicating can be carried out formally through official communication channels, or occurred through informal interactions, such as meeting, and conversations. Both the formal and informal modes of communication play significant roles in B2B decision making. In this study, communication can be defined as "the formal as well as informal sharing of meaningful and timely information between firms" (Anderson and Narus[20]). This definition implies that exchange of information between supplier and customer occurs in timely and meaningful manner. Ramaseshan, Rabbanee, and Tan [28] agreed that frequent and timely exchange of information is vital to maintain contact with key personnel in B2B market. Additionally, Anderson and Narus[20] pointed out that communication is not confined to official communication channels only.

Pecinova et al.[21] demonstrated that cooperation can positively affect customer loyalty. According to their argument, a supplier cooperates by investing in the relationship to be able to effectively create highest possible perceived value for customer. In return, the supplier gains reciprocity benefits, in term of long term business stability, growth and profitability. Both supplier and customer are loyal to the relationship, because both of them benefit from the cooperation. McDonnell et al.[24] emphasized the important to maintain cooperative long term relationship. In their study on franchisee loyalty toward franchisor, they determined a highly cooperatively relationship creates high level of loyalty toward franchisor. Yang et al.[25] found similar highly cooperative environment has significant influence on customer loyalty.
Accordingly, when the relationship was highly cooperative, their finding indicated high degree of customer loyalty existed toward the supplier. Cooperation is a crucial factor that affects customer loyalty, and should be emphasized in the business relationship. Therefore, this study proposes the hypothesis that cooperation has significant influence on customer loyalty of Malaysian E\&E manufacturing firms towards suppliers in Malaysian E\&E manufacturing industry.

H8: Communication has significant influence on customer loyalty

Communicating is particularly crucial in international B2B business. The more open communication between suppliers and customers, the more likey customers commit to the relationships. In the E\&E manufacturing industry, open communication includes keeping each parties, namely suppliers and customers, informed about changes to the processes, material, schedule, and specificaitons, information of mutual benefit about events and changes in the market. The acts of ensuring information availability and information quality play significant role in the development of trust and commitment in the relationship between suppliers and customers. Chen, Yen, Rajkumar, and Tomochko[29] demonstrated that information sharing has direct influence on commitment. Communication can reduce information asymmetric, when the customers are kept abreast with the current information by trusted supplier. Kang and Jindal [30] demonstrated that effective and frequent communication develops trust-commitment relationship that is essential to curtail opportunism. Based on the above arguments, there are amber evidences that communication and commitment is significantly related. Therefore, this study hypothesizes that commitment has significant influence on commitment of Malaysian E\&E manufacturing firms towards their suppliers in Malaysian E\&E manufacturing industry.

H9: Communication has significant influence on commitment

\subsection{Mediation Effects of Commitment}

Commitment has been reported in extant relationship marketing studies plays key function in mediating business relationship. Cater and Cater[4] determined that the relationship between product quality and customer loyalty is mediated by commitment in manufacturing industry. In the same study, they found that the relationship between cooperation and customer loyalty is mediated by commitment. Hsu, Wang, and Chih[31] demonstrated that commitment mediates the relationship between trust and customer loyalty in the B2B e-commerce industry. Human and Naude[32] has shown that the relationship between communication and customer loyalty is mediated commitment in computer-aided industry. Judging from the findings in previous marketing 
relationship, there were sufficient evident to demonstrate that commitment has significant mediating effects on the relationships between product quality and customer loyalty, trust and customer loyalty, cooperation and customer loyalty, and communication and customer loyalty. Thus, this study proposed four hypotheses, where commitment has significant mediating effects on the relationships between product quality, trust and cooperation toward customer loyalty of Malaysian E\&E manufacturing firms toward their suppliers in Malaysian E\&E manufacturing industry.

H10: Commitment significantly mediates the relationship between product quality and customer loyalty.

H11: Commitment significantly mediates the relationship between trust and customer loyalty.

H12: Commitment significantly mediates the relationship between cooperation and customer loyalty.

H13: Commitment significantly mediates the relationship between communication and customer loyalty.

\section{Theoretical Framework}

Based on the underpinning theories of social exchange theory and social capital theory, concepts of product differentiation and relationship marketing, and supporting evidences from previous relationship marketing and supply chain literatures, a theoretical framework is developed in Figure 1.0 depicting the predictors, mediator and dependent variables, and their linkages. The theoretical framework illustrates two types of relationships. The first type of relationships involves direct influences of product quality, trust, cooperation and commitment on customer loyalty. The second type of relationships concerns about the indirect influences of product quality, trust, cooperation, and communication toward customer loyalty via commitment.

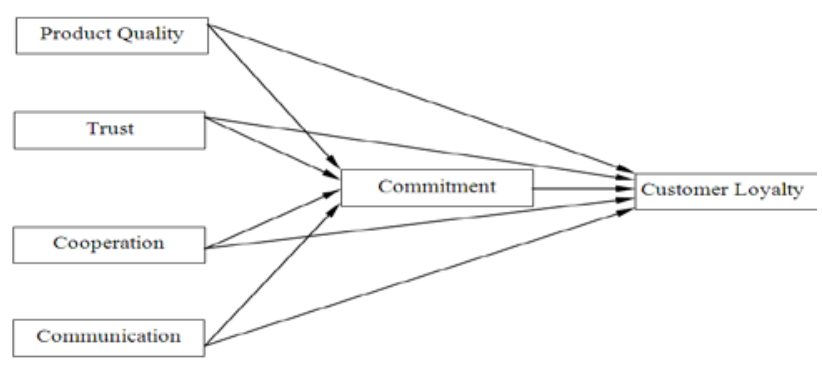

Figure 1. Theoretical framework

\section{Methodology}

A cross-sectional study was adopted to collect data from customers, which are E\&E manufacturing firms operating in Malaysian E\&E manufacturing industry. The sampling frame consists of E\&E manufacturing firms listed in Federation of Malaysian Manufacturers Industry Directory (FMM[33]), and Malaysia External Trade Development Corporation (MATRADE) directory for computer hardware, consumer and industrial E\&E products, telecommunication, and E\&E parts and components (MATRADE[34]). The E\&E manufacturing firms in these two directories represent four sub-sectors of Malaysian E\&E industry, namely Electronics-Components, Electronics-Consumer, Electronics-Industrial, and Electrical. Sampling table established by Krejcie and Morgan[35], and systematic random sampling procedure were deployed to randomly select E\&E manufacturing firms from the two directories. A minimum sample size of 265 samples should be obtained from the questionnaire survey. Survey questionnaires were sent to the selected Malaysian E\&E manufacturing firms, where only one response was allowed from each of them. The unit of analysis was organization. The respondents were general managers, factory managers, managers or senior executives with decision making responsibility for managing suppliers. The data collection period was a three months period toward the end of year 2017.

The survey questionnaire has two sections, where the first section contains questionnaires designed to collect demographic information about the Malaysian E\&E manufacturing firms, and the second section consists of measurement scales for customer loyalty, product quality, trust, cooperation, communication, and commitment. The measurement scale for customer loyalty was adapted from Askariazad and Babakhani [36]). It has five measurement items. Product quality was measured by six items, which were adapted from measurement scale developed by Ulaga and Eggert[37]. Trust was measured by 10 items, which were adapted from Chen et al.[29]. Cooperation was measured by six items, which were adapted from Cannon and Perreault[22]. Communication was measured by six items, which were adapted from Krause and Ellram[38). Commitment was measured by six items, which were adapted from Ulaga and Eggert[37]. All the six measurement scales were rated with 7-point Likert scale, which measured from 1 (strongly disagree) to 7 (strongly agree).

The measurement scales were confirmed with sufficient face validity and content validity through a pre-testing, which was conducted by six experts in the fields of relationship marketing and supply chain management. A pilot run was then performed to determine the internal consistency reliability of the measurement scales, where the determined Cronbach's Alpha indicators for measurement scales customer loyalty (0.812), product quality (0.801), trust $(0.848)$, cooperation $(0.820)$, communication (0.842), and commitment $(0.816)$ were greater than threshold value of 0.7 (Nunnally[39]). All six measurement scales have adequate internal consistency 
reliability.

A total of 276 survey questionnaires were returned from the questionnaire survey. The returned survey questionnaires were initially screened for completeness, where nine survey questionnaires were rejected and removed from subsequent data analysis due to excessive errors and missing information. Response rate was 38\%, which was deemed acceptable given the low response rate associated with mail surveys commonly found in the Malaysian industry (Khor \& Udin[40]). Moreover, the amount of valid survey questionnaires were more than the minimum sample size of 265 as determined from Krejcie and Morgan [35]) sampling table.

Data from the survey questionnaires was further screened for error in normality distribution, non-response bias, common method bias, and multicollinearity. Normality of data distributions were inspected through skewness and kurtosis, where the data distributions for customer loyalty, product quality, trust, cooperation, communication, and commitment variables exhibited z-values within the threshold limits \pm 2.58 indicating the data were distributed normally (Hair et al.[41]). Screening of non-response bias was conducted by segregating the data into two groups, namely, early responses, where survey questionnaires returned within one month from initial distribution, and late responses containing survey questionnaires returned after one month. Statistical independent t-testing was applied to test the difference of means between the two groups, where the finding determined that there was no significant difference in means between the two groups. It was concluded that non-response bias was not significantly present in the data. As for screening of common method bias, Harman's single-factor score was deployed, where all the 33 factor items are loaded into one single factor item in the factor analysis. The un-rotated factor solution for 33 factor items into a single factor item yielded $27.335 \%$ of the variance, which was less than threshold limit of $50 \%$ (Eichhorn[42]). Thus, the Harman's single-factor score test result indicated that common method bias was not significantly present in the data, and unlikely to yield measurement error in data analysis. Variance Inflation Factor (VIF) indicators for two endogenous constructs, namely commitment and customer loyalty, were determined less than five (Hair et al.[41]). The findings implied that multicollinearity was not significantly present in the structural model.

Descriptive analysis determined that the data has representation of Electronics-Components (36\%), Electronics-Consumer (24\%), Electronics-Industrial (22\%), and Electrical (19\%). The E\&E manufacturing firms were represented by fully local-owned (46\%), fully foreign-owned (28\%), 51\% to 99\% local ownership (8\%), and $51 \%$ to $99 \%$ foreign ownership (14\%). Based on the 7-points Likert scale ratings, the average scores determined for customer loyalty, product quality, trust, cooperation, communication, and commitment are six respectively. The descriptive analysis findings implied that respondents agreed that customer loyalty, product quality, trust, cooperation, communication, and commitment were important factors in their E\&E manufacturing business.

\section{Findings and Discussion}

Table 1 showed the results of PLS-SEM analysis for indicator reliability, internal consistency reliability and convergent validity of the reflective measurement model. Indicator reliability was established with the retained indicators that met the requirements recommended by Hair, Sarstedt, Hopkins, and Kuppelwieser[43]. Internal consistency reliability was measured by composite reliability rather than Cronbach's Alpha indicator to avoid underestimating the internal consistency reliability. The determined composite reliability ranged from 0.811 to 0.837 , which were greater than the recommended threshold limit of 0.7 (Nunnally[39]) indicating that the measurement model has sufficient internal consistency reliability. Convergent validity was determined by the Average Variance Extracted (AVE), where the determined AVE ranged from 0.522 to 0.536 , which were greater than the critical limit of 0.50 (Hair et al., 2014) indicating the convergent validity were sufficiently established in the reflective measurement model.

Discriminant validity of the reflective measurement model was determined by comparing the squared root of AVE against bivariate correlation of values. Table 2 showed that all determined squared root AVE were greater than their respective bivariate correlation values, which implied that reflective measurement model has established discriminant validity (Fornell \& Larcker[44]). With the indicator reliability, composite reliability, discriminant validity, and convergent validity established, thus, the reflective measurement model was determined valid and reliable for assessment of structural model. 
Electrical and Electronics Manufacturing Industry

Table 1. Analysis results for indicator reliability

\begin{tabular}{|c|c|c|c|c|}
\hline Variable & Measurement item & Indicator reliability & AVE & Composite reliability \\
\hline \multirow[t]{4}{*}{ Customer loyalty (CL) } & CL2 & 0.776 & 0.533 & 0.820 \\
\hline & CL3 & 0.738 & & \\
\hline & CL4 & 0.701 & & \\
\hline & CL5 & 0.701 & & \\
\hline \multirow[t]{4}{*}{ Product quality (PQ) } & PQ1 & 0.704 & 0.527 & 0.816 \\
\hline & PQ3 & 0.707 & & \\
\hline & PQ4 & 0.750 & & \\
\hline & PQ5 & 0.769 & & \\
\hline \multirow[t]{4}{*}{ Trust (TR) } & TR2 & 0.708 & 0.536 & 0.822 \\
\hline & TR5 & 0.711 & & \\
\hline & TR6 & 0.775 & & \\
\hline & TR7 & 0.766 & & \\
\hline \multirow[t]{5}{*}{ Cooperation (CO) } & $\mathrm{CO} 2$ & 0.660 & 0.529 & 0.837 \\
\hline & $\mathrm{CO} 3$ & 0.774 & & \\
\hline & $\mathrm{CO} 4$ & 0.776 & & \\
\hline & $\mathrm{CO} 5$ & 0.728 & & \\
\hline & CO6 & 0.715 & & \\
\hline \multirow[t]{4}{*}{ Communication (CN) } & CN1 & 0.744 & 0.522 & 0.830 \\
\hline & CN4 & 0.723 & & \\
\hline & CN5 & 0.834 & & \\
\hline & CN6 & 0.758 & & \\
\hline \multirow[t]{4}{*}{ Commitment (CM) } & CM1 & 0.720 & 0.528 & 0.811 \\
\hline & CM2 & 0.728 & & \\
\hline & CM3 & 0.725 & & \\
\hline & CM6 & 0.704 & & \\
\hline
\end{tabular}

Table 2. Analysis results for discriminant validity

\begin{tabular}{|c|c|c|c|c|c|c|}
\hline Latent variable & CL & PQ & TR & CO & CN & CM \\
\hline Customer loyalty (CL) & $\mathbf{0 . 7 3 0}$ & & & & & \\
\hline Product quality (PQ) & 0.438 & $\mathbf{0 . 7 2 6}$ & & & & \\
\hline Trust (TR) & 0.377 & 0.398 & $\mathbf{0 . 7 4 1}$ & & & \\
\hline Cooperation (CO) & 0.478 & 0.393 & 0.536 & $\mathbf{0 . 7 1 3}$ & & \\
\hline Communication (CN) & 0.386 & 0.409 & 0.482 & 0.525 & $\mathbf{0 . 7 4 3}$ & \\
\hline Commitment (CM) & 0.500 & 0.364 & 0.440 & 0.442 & 0.486 & $\mathbf{0 . 7 2 0}$ \\
\hline
\end{tabular}

Note: Diagonals (bolded) represent the square root AVE values, and off-diagonals represent bivariate correlations values.

The assessment of structural model determined significant of nine hypothesized relationships, H1, H2, H3, H4, H5, H6, H7, H8, and H9, and their respective path coefficients. Bootstrapping procedure with 4,999 re-samplings (Henseler, Hubona \& Ray[45]), and statistical independent t-testing were deployed to test the significant of the hypothesized relationships. Table 3 showed the results of independent t-statistics testing with reference to the hypotheses. Hypothesized relationships with reference to $\mathrm{H} 1, \mathrm{H} 2, \mathrm{H} 3, \mathrm{H} 5, \mathrm{H} 6, \mathrm{H} 7$, and $\mathrm{H} 9$ were significant. Thus, respective hypotheses were supported.

Their path coefficients ranged from 0.171 to 0.397 , which were positive indicating the relationships were direct and positive-direction. However, two hypothesized relationships with reference to $\mathrm{H} 4$, and $\mathrm{H} 8$ were not significant, and thus the respective hypotheses were not supported.

The predictive accuracy of structural model was determined by coefficient of determination $\left(\mathrm{R}^{2}\right)$, which indicated the amount of variance absorbed by the exogenous variable that was contributed by the endogenous variables linked to it. Analysis results of the $\mathrm{R}^{2}$ and classification of predictive accuracy for the structural model showed that the amount of variances 
absorbed by the two exogenous variables, namely commitment and customer loyalty, were $37.2 \%$ and $47.4 \%$ respectively. The predictive accuracy values were greater than 0.25, which Cohen [46] classified the predictive accuracy was substantial and significant. Thus, structural model in this study has substantial and significant predictive power.

Table 4 showed the findings of mediating effects with bootstrapping of 265 cases with 4,999 re-samplings. The mediation effects were determined by bootstraps, and the sampling distributions of indirect effects (Preacher \& Hayes [47]). Findings in Table 4 highlighted the important role of commitment in mediating all four relationships, namely product quality towards customer loyalty, trust towards customer loyalty, cooperation towards customer loyalty, and communication toward customer loyalty. Following the recommendation from Preacher and Hayes [47], the upper bound (97.25\%) and lower bound (2.5\%) of confident intervals of all four mediated relationships did not include zero values. Thus, all four mediated relationships were significant, and hypotheses H10, H11, H12 and H13 were supported. Table 5 showed the strength of mediation as indicated by Variance Accounted For (VAF), which was computed by dividing the indirect effect with total effect. The VAF value should range from 0 to 1 , where 1 indicating full mediation, in-between 0.2 to 0.8 implying partial mediation, and less than 0.2 indicating no significant mediation (Hair, Hult, Ringle, and Sarstedt[48]. VAF values for the paths product quality-commitment-customer loyalty, and cooperation-commitment-customer loyalty were 0.280 and 0.243 respectively. Thus, the two relationships were partially mediated by commitment respectively. VAF values for paths trust-commitment-customer loyalty, and communication-commitment-customer loyalty indicated that the relationships between trust and customer loyalty, and communication and customer loyalty were fully mediated by commitment respectively.

Table 3. Analysis results for path coefficients and direct relationships

\begin{tabular}{|c|c|c|c|c|c|}
\hline Hypothesis & Relationship & Beta & t-statistic & p-value & Finding \\
\hline H1 & CM-CL & 0.297 & 4.698 & $0.000 * *$ & Supported \\
\hline H2 & PQ-CL & 0.221 & 4.061 & $0.000 * *$ & Supported \\
\hline H3 & PQ-CM & 0.291 & 4.061 & $0.000 * *$ & Supported \\
\hline H4 & TR-CL & 0.022 & 0.364 & 0.358 & Not supported \\
\hline H5 & TR-CM & 0.177 & 2.607 & $0.005 * *$ & Supported \\
\hline H6 & CO-CL & 0.240 & 3.936 & $0.000 * *$ & Supported \\
\hline H7 & CO-CM & 0.259 & 4.625 & $0.000 * *$ & Supported \\
\hline H8 & CN-CL & 0.015 & 0.223 & 0.412 & Not supported \\
\hline H9 & CN-CM & 0.268 & 3.836 & $0.000 * *$ & Supported \\
\hline
\end{tabular}

Note: t-statistic (significant level) for significant: $1.645(\mathrm{p}<0.05)^{*}$, and $2.33(\mathrm{p}<0.01)^{* *}$

Table 4. Analysis results for mediation effects

\begin{tabular}{|c|c|c|c|c|c|c|c|}
\hline & & & & \multicolumn{2}{|c|}{$\begin{array}{c}\text { 95\% bootstrapped } \\
\text { confidence interval }\end{array}$} & Finding \\
\hline Hypothesis & Path & $\begin{array}{c}\text { Indirect } \\
\text { effect (a x } \\
\text { b) }\end{array}$ & t-statistic & p-value & $\begin{array}{c}\text { Upper } \\
\text { bound }\end{array}$ & $\begin{array}{c}\text { Lower } \\
\text { bound }\end{array}$ & Sound \\
\hline H10 & PQ-CM-CL & 0.086 & 2.975 & $0.005 * *$ & 0.011 & 0.099 & Supported \\
\hline H11 & TR-CM-CL & 0.053 & 2.247 & $0.025 *$ & 0.013 & 0.105 & Supported \\
\hline H12 & CO-CM-CL & 0.077 & 2.471 & $0.009 * *$ & 0.015 & 0.108 & Supported \\
\hline H13 & CN-CM-CL & 0.080 & 2.971 & $0.003 * *$ & 0.033 & 0.138 & Supported \\
\hline
\end{tabular}

Note: t-statistic (confident intervals) for significant: $1.96(\mathrm{p}<0.05)^{*}$, and $2.58(\mathrm{p}<0.01)^{* *}$

Table 5. VAF index analysis results for mediation effects

\begin{tabular}{|c|c|c|c|c|c|}
\hline Path & Indirect effect & Direct effect & Total effect & VAF & Mediation effect \\
\hline PQ-CM-CL & 0.086 & 0.221 & 0.307 & 0.280 & Partial mediation \\
\hline TR-CM-CL & 0.053 & - & 0.053 & 1.000 & Full mediation \\
\hline CO-CM-CL & 0.077 & 0.240 & 0.317 & 0.243 & Partial mediation \\
\hline CN-CM-CL & 0.080 & - & 0.080 & 1.000 & Full mediation \\
\hline
\end{tabular}




\section{Conclusions}

The findings of this study have determined that the relationship between product quality and customer loyalty is significant in Malaysian E\&E manufacturing industry. In addition, the relationship between product quality and customer loyalty was partially mediated by commitment. Product quality is an essential aspect of product differentiation, which is important for suppliers in Malaysian E\&E manufacturing industry to develop customer loyalty. In Malaysian E\&E manufacturing industry, suppliers can develop customer loyalty with the direct influence of product quality. In additional, suppliers can develop customer loyalty indirectly by putting efforts on product quality to gain commitment, which subsequently influences customer loyalty.

In Malaysian E\&E manufacturing industry, relational elements do not influence customer loyalty the same ways. The relationship between cooperation and customer loyalty was significant, but the relationships between trust and customer loyalty, and communication and customer loyalty were not significant. The relationships between all three relational elements and customer loyalty became significant when the mediating effects of commitment were present. The relationship between cooperation and customer loyalty was partially mediated by commitment, and the relationships between trust and customer loyalty, and communication and customer loyalty were fully mediated by commitment. As such, trust and communication do not develop customer loyalty directly in Malaysian E\&E manufacturing industry. It is important for suppliers to focus on gaining customer commitment, because of its significant influence on customer loyalty. In contrast, cooperation can develop customer loyalty directly, as well as indirectly with the partial mediating effect of commitment. In summary, trust, cooperation, and communication are significant relational elements of relationship marketing, in which trust and communication develop customer loyalty differently from cooperation in Malaysian E\&E manufacturing industry.

\section{Managerial Implications}

Suppliers in E\&E manufacturing industry should offer products that are meeting specification, and provide values to customers. Products with consistent quality can develop loyal relationships with customers. Findings from this study have determined that product quality can influence customer loyalty directly and as well as indirectly with the presence of mediating effects of commitment. Products with consistent quality are beneficial to customers' operations. Customers are loyal to the relationships when they experience that they are getting values from products with consistent quality. Additionally, product quality can also lock-in (calculatively commitment) customers to the relationships, where customers may have difficulties to find alternative products with high standard of quality from elsewhere in the market. Committed customers are loyal to the relationships with suppliers, in order to continue receiving the supplies of the products.

Malaysian E\&E manufacturing industry is very competitive, where suppliers continuously make efforts to out-do each other's. Due to this nature of aggressive competition, it is becoming more difficult for suppliers to differentiate themselves from competitions solely on the basis of product differentiation, such as product quality. Although product quality is still important, the marketing emphasis is gradually shifting towards developing unique relationships with customers, where the relationships are not easily imitated by competitors Managers in the supplier firms should manage the marketing emphasis shift efficiently by utilizing the influences of product quality, and relational elements, namely trust, cooperation, and communication, on customer loyalty complementary.

When applying the approach involving influences of relational elements (trust, cooperation, and communication), on customer loyalty, managers in supplier firms should take cautions, because not all the relational elements influence customer loyalty in the same ways. As established in this study, only cooperation can influence customer loyalty both directly and indirectly with the presence of partial mediating effect of commitment. In contrast, trust and communication have no effect on customer loyalty directly. They can only influence customer loyalty with the presence of full mediation effect of commitment. Managers in the supplier firms are recommended to adopt the influences of relational elements wisely to maximize their efforts in establishing commitment, and customer loyalty with customers.

As determined in this study, the dependency of commitment on trust suggests managers in supplier firms should act in ways that are trustworthy, reliable, credible, capable, and with integrity as perceived by their customers. They should avoid focusing on gaining customer loyalty directly, rather pay more attention to developing commitment from customers. For instance, they should act with credibility and integrity when reporting manufacturing problems or potential risks to customers, and demonstrating that they are reliable and capable to resolve the manufacturing problems in timely manner. When the customers correctly perceive that the suppliers have taken sincere initiatives and value their relationships, good chances exist that they are more trustful, and as a result more committed, and loyal to the suppliers.

Cooperative relationship between suppliers and customers are vital in the technological and market demands driven E\&E industry. This notion has been confirmed in this study, where cooperation can influence customer loyalty both directly and indirectly. Managers in supplier firms are suggested to embrace cooperative 
behaviours when they are participating in business problem resolutions with customers. Such cooperative behaviours are source of values, which can lead to customer loyalty. The ability to gain commitment and loyalty from customers depends on extend the suppliers invest efforts in the cooperative relationships. Suppliers are suggested to take initiatives by creating cooperative behaviours that can generate highest possible values for customers. When the customers experience the initiatives and values from the cooperative behaviours, they respond with reciprocity benefits via commitment and loyalty to the suppliers.

\section{Limitations of Study}

There are several notable limitations that can be considered by future studies exploring the same field. This study is based a cross-sectional approach, where data is collected from E\&E Malaysian E\&E manufacturing firms at a single point of time. It is suggested that future studies to extend this study by considering longitudinal study, in which data is collected over long period of time to observe the changes of characteristics in the variables. The longitude study can examine linkages between variables and their interactions over long period of time, which takes into consideration the changing business environments that may happen in Malaysian E\&E manufacturing industry. The sample frame was confined to samples of E\&E manufacturing firms randomly drawn from two directories, namely FMM Industry Directory (FMM, 2016), and MATRADE directory for computer hardware, consumer and industrial E\&E products, telecommunication, and E\&E parts and component (MATRADE, 2016). However, not all E\&E manufacturing firms in Malaysia were registered in these two directories. In additional, this study came across inaccurate data and outdated information in both directories. It is recommended that future studies to enlarge the sample frame, where representative samples can be randomly taken from more directories. The relationship marketing approach was confined to three relational elements, namely trusts, cooperation, and communication, in this study. Other relevant relational elements may exist. It is suggested that future studies to enrich this study by examining additional relational elements that may have impacts on commitment and customer loyalty.

\section{REFERENCES}

[1] Bank Negara Malaysia. Annual Report 2015. Retrieved from http://www.bnm.gov.my/files/publication/ar/en/2015/ ar2015_book.pdf

[2] Li, C. (2013). Sourcing for supplier effort and competition:
Design of the supply base and pricing mechanism. Management Science, 59(6), 1389-1406.

[3] Wu, L. Y., Chen, P. Y., \& Chen, K. Y. (2015). Why does loyalty-cooperation behavior vary over buyer-seller relationship? Journal of Business Research, 68(11), 1-8.

[4] Cater, T., \& Cater, B. (2010). Product and relationship quality influence on customer commitment and loyalty in B2B manufacturing relationships. Industrial Marketing Management, 39 (8), 1321-1333.

[5] Morgan, R. M., Hunt, S. D. (1994). The commitment-trust theory of relationship marketing. Journal of Marketing, 58(3), 20-28

[6] Kim, S. H., Kim, J. H., \& Lee, W. J. (2018). Exploring the impact of product service quality on buyer commitment and loyalty in B TO B relationships. Journal of Business-to-Business Marketing, 25(2), 91-117.

[7] De Ruyter, K., Moorman, L., \& Lemmink, J. (2001). Antecedents of commitment and trust in customer-supplier relationships in high technology markets. Industrial Marketing Management, 30(3), 271-286.

[8] Hetesi, E. (2014). The effects of recession on B2B loyalty. Journal of Marketing Development and Competitiveness, 8(2), 26-37.

[9] Loureiro, S. M. C., \& Kastenholz, E. (2011). Corporate reputation, satisfaction, delight, and loyalty towards rural lodging units in Portugal. International Journal of Hospitality Management, 30(3), 575-583.

[10] Rai, A. K. (2012) Customer relationship management: Concepts and cases ((2nd. ed.), New Delhi, India: PHI Learning.

[11] Moorman, C., Zaltman, G., \& Deshpande, R. (1992). Relationships between providers and users of market research: the dynamics of trust within and between organizations. Journal of Marketing Research, 29, 314-28.

[12] Doma, S. S. B. (2013). Relationship quality as predictor of B2B customer loyalty. Systemics. Cybernetics and Informatics, 11(1), 72-78, 2013.

[13] Garvin, D. A. (1984). What does "product quality” really mean? Sloan Management Review, Fall, 25-45.

[14] Crosby, P. B. (1979). Quality is free. The art of making quality certain, New York, USA: New American Library.

[15] Sadeghi, M. A., Mollahosseini, A., \& Forghani, M. (2014). A study on the effect of product quality on behavioral and attitudinal loyalty: A case study of SME companies. Management Science Letter, 4, 1764-1650.

[16] Lin, M. J. J., \& Huang, C. H. (2013). The impact of customer participation on NPD performance: the mediating role of inter - organization relationship. Journal of Business \& Industrial Marketing, 28(1), 3-15.

[17] Velazquez, B. M., Gil-Saura, I., \& Molina, M. E. R. (2011). Conceptualizing and measuring loyalty: Towards a conceptual model of tourist loyalty antecedents. Journal of Vacation Marketing, 17 (1), 65-81.

[18] Jiang, Z., Henneberg, S. C., \& Naude, P. (2011). Supplier relationship management in the construction industry: the 
effects of trust and dependence. Journal of Business \& Industrial Marketing, 27(1), 3-15.

[19] Chao, C. M., Yu, C. T., Cheng, B. W., \& Chuang, P. C. (2013). Trust and commitment in relationships among equipment suppliers: Transaction cost and social exchange theories. Social Behavior and Personality, 41(7), 1057-1070.

[20] Schiele, H., Veldman, J., Huttinger, L., \& Pulles, N. (2012). Towards a social exchange theory perspective on preferred customership - concept and practice. Retrieved from https://link.springer.com/content/pdf/10.1007\%2F97 8-3-8349-3928-9_6.pdf

[21] Anderson, J. C., \& Narus, J. A. (1990). A model of distributor firm and manufacturing firm working partnership. Journal of Marketing, 54, 42-58.

[22] Cannon, J. P., \& Perreault Jr, W. D. (1999). Buyer-seller relationships in business markets. Journal of Marketing Research, 36(4), 439-460.

[23] Pecinova, Z., Lostakova, H. \& Branska, L. (2013). The benefits of deepening cooperation - the supplier's view. Retrieved fromhttp://www.wseas.us/e-library/conferences/ 2013/Dubrovnik/MATREFC/MATREFC-18.pdf

[24] McDonnell, J., Beatson, A., \& Huang, C. H. (2011). Investigating relationships between relationship quality, customer loyalty and cooperation: An empirical study of convenience stores' franchise chain systems. Asia Pacific Journal of Marketing and Logistics, 23(3), 367-385.

[25] Yang, C. Y., Chen, P. S., \& Chien, Y. H. (2014). Customer expertise, affective commitment, customer participation, and loyalty in B2B services. The International Journal of Organizational Innovation, 6(4), 174-183.

[26] Sharma, N., Young, L. C., \& Wilkinson, Y. I. (2015). The nature and role of different types of communication in inter-firm relationship cooperation. Journal of Business \& Industrial Marketing, 30(1), 45-59.

[27] Hutchinson, D., Singh, J., Svensson, G., \& Mysen, T. (2012). Inter-relationships among focal dimensions in relationship quality: a quantitative and exploratory approach. International Journal of Procurement Management, 5(2), 229-252.

[28] Ramaseshan, B., Rabbanee, F. K., \& Tan, H. H. L. (2013). Effects of customer equity drivers on customer loyalty in B2B context. Journal of Business \& Industrial Marketing, 28(4), 335-346.

[29] Chen, J. V., Yen, D. C., Rajkumar, T. M., \& Tomochko, N. A. (2011). The antecedent factors on trust and commitment in supply chain relationships. Computer Standards \& Interfaces, 33(3), 262-270.

[30] Kang, B., \& Jindal, R. P. (2015), Opportunism in buyer-seller relationships: Some unexplored antecedents. Journal of Business Research, 68(3), 735-742.

[31] Hsu, L. C., Wang, K. Y., \& Chih, W. H. (2013). Effects of web site characteristics on customer loyalty in B2B e-commerce: evidence from Taiwan. The Service Industries Journal, 33(11), 1026-1050.

[32] Human, G, \& Naude, P. (2014). Heterogeneity in the quality-satisfaction-loyalty framework. Industrial
Marketing Management, 43(6), 920-928.

[33] FMM. (2016). Company and product search. Retrieved December, 11, 2016, from http://www.fmm.org.my/Memb er_List.aspx?SearchType=Product\&Keyword=

[34] MATRADE. (2016). Malaysia products directory. RetrievedDecember, 11, 2016, from http://www.matrade.g ov.my/en/malaysian-exporters/showcasing-malaysia-expor t/directory/malaysia-products-directory

[35] Krejcie, R. V., \& Morgan, D. W. (1970). Determining sample size for research activities. Educational and Psychological Measurement, 30(3), 607-610.

[36] Askariazad, M. H., \& Babakhani, N. (2015). An application of European Customer Satisfaction Index (ECSI) in business to business (B2B) context. Journal of Business \& Industrial Marketing, 30(1), 17-31.

[37] Ulaga, W., \& Eggert, A. (2006). Value-based differentiation in business relationships: Gaining and sustaining key supplier status. Journal of Marketing, 70(1), 119-136.

[38] Krause, D. R., \& Ellram, L. M. (1997). Success factors in supplier development. International Journal of Physical Distribution \& Logistics Management, 27(1), 39-52.

[39] Nunnally, J. C. (1978). Psychometric theory (2nd. ed.), New York, USA: McGraw-Hill

[40] Khor, K. S., \& Udin, Z. M. (2012). Impact of reverse logistics product disposition towards business performance in Malaysian E\&E companies. Journal of Supply Chain and Customer Relationship Management, 2012(2012), $1-19$.

[41] Hair, J. F., Black, W. C., Babin, B. J., Anderson, R. E., \& Tatham, R. L. (2007). Multivariate Data Analysis (6th. ed.). Upper Saddle River, NJ: Pearson Prentice Hall.

[42] Eichhorn, B. R. (2014). Common method variance techniques. Retrieved from https://www.lexjansen.com/m wsug/2014/AA/MWSUG-2014-AA11.pdf

[43] Hair, J. F., Sarstedt, M., Hopkins, L., \& Kuppelwieser, V. G. (2014). Partial least squares structural equation modeling (PLS-SEM) An emerging tool in business research. European Business Review, 26(2), 106-121.

[44] Fornell, C., \& Larcker, D. F. (1981). Evaluating structural equation models with unobservable variables and measurement error. Journal of Marketing Research, 18(1), 39-50.

[45] Henseler, J., Hubona, G., \& Ray, P. A. (2016). Using PLS path modeling in new technology research: Updated guidelines. Industrial management \& data systems, 116(1), $2-20$.

[46] Cohen, J. (1988). The analysis of variance. In statistical power analysis for the behavioral sciences. Hillsdale, New York: Lawrence Erlbaum Associates Publishers.

[47] Preacher, K. J., \& Hayes, A. F. (2008). Asymptotic and resampling strategies for assessing and comparing indirect effects in multiple mediator models. Behavior Research Methods, 40(3), 879-891.

[48] Hair, J. F., Hult, G. T. M., Ringle, C. M., and Sarstedt, M. 
(2017). A Primer on Partial Least Squares Structural Equation Modeling (2nd edition). Thousand Oaks: Sage. 